\title{
Ovarian Clear Cell Adenofibroma
}

National Cancer Institute

\section{Source}

National Cancer Institute. Ovarian Clear Cell Adenofibroma. NCI Thesaurus. Code C40085.

An uncommon benign neoplasm of glandular epithelium characterized by the presence of clear or hobnail cells within a dense fibrous stroma. 